\section{Creeping Bentgrass Physiological Responses to Natural Plant Growth Regulators and Iron Under Two Regimes}

\author{
Xunzhong Zhang', R.E. Schmidt, E.H. Ervin, and S. Doak \\ Department of Crop and Soil Environmental Sciences, Virginia Polytechnic \\ Institute and State University, Blacksburg, VA 24061-0404 \\ Additional index words. chlorophyll fluorescence, humic acid, phytochemical activity, \\ seaweed extract, superoxide dismutase
}

\begin{abstract}
Creeping bentgrass (Agrostis palustris Huds.) is an extensively used cool-season grass for fine turf areas such as golf course putting greens, but suffers from poor summer stress tolerance. These studies were conducted to investigate the influences of natural plant growth regulators (NPGR) and Fe on creeping bentgrass photochemical activity (PA), antioxidant superoxide dismutase (SOD) activity, root growth and leaf color under two fertilization regimes. The bentgrass was maintained in well-watered field conditions or water-stressed glasshouse conditions. A mature bentgrass was treated monthly during the field season with seaweed (Ascophyllum nodosum Jol.) extract (SWE) at 50 $\mathrm{mg} \cdot \mathrm{m}^{-2}$ or humic acid (HA) at $150 \mathrm{mg} \cdot \mathrm{m}^{-2}$ or in combination with or without $\mathrm{FeSO}_{4}$ at 520 $\mathbf{m g} \cdot \mathbf{m}^{-2}$ and grown under a low or a high fertilization regime. Foliar application of SWE + Fe increased PA $(14 \%$ to $15 \%)$, while applications of SWE + HA or SWE + HA + Fe increased SOD activity (49\% to 114\%) of creeping bentgrass in Summer 1997 and Summer 1998. There was no significant fertilization $\times$ NPGR interaction for PA and SOD activity. Bentgrass PA was increased by $13 \%$ to $46 \%$ when treated with NPGR with or without Fe compared to the control measured in May. The addition of Fe with each NPGR application improved fall and winter leaf color. All NPGR and Fe treatments increased root mass (17\% to 29\%) in Aug. 1997 and 1998, except HA alone in 1998. Under sustained low soil moisture ( $-0.5 \mathrm{MPa})$ conditions, application of NPGR with or without $F e$ increased $P A$ and SOD activity. The data indicate that SWE and $H A$ enhance the physiological function of 'Southshore' creeping bentgrass, resulting in improved root growth regardless of low or high fertilization regime. However, addition of Fe to these NPGR served primarily to improve late season leaf color. The results suggest that, in addition to maintaining adequate plant-available nutrients, applications of natural PGRs, such as SWE and HA, prior to and during summer abiotic stresses would be beneficial.
\end{abstract}

Creeping bentgrass is the primary turfgrass used on temperate to warm-humid climate zone golf course putting greens. Creeping bentgrass quality is frequently reduced by environmental stresses such as drought and supraoptimal temperatures (White, 1996). In addition, improper fertilization practices, such as excess nitrogen inputs, may reduce the tolerance of this grass to environmental stress and result in poor turf quality, especially during the summer (Schmidt and Zhang, 1997).

Environmental stress damages plant cells through a production of reactive oxygen species (ROS) (superoxide, hydrogen peroxide, hydroxyl anion, and singlet oxygen) (Smirnoff, 1995). Plant antioxidant metabolites and enzymes (such as superoxide dismutase) protect cells by scavenging ROS (Zhang and Kirkman, 1994). Greater antioxidant contents have been associated positively

Received for publication 25 Apr. 2001. Accepted for publication $10 \mathrm{Jan} .2002$.

${ }^{1}$ To whom reprint requests should be addressed. E-mail address: xuzhang@vt.edu with increased plant stress tolerance (Smirnoff, 1995; Zhang and Schmidt, 1999). It is well known that energy in Photosystem II (PSII) is released in the form of chlorophyll fluorescence (Krause and Somersalo, 1989). When plants experience environmental stress, photosynthetic electron transport is inhibited and chlorophyll fluorescence increases rapidly. Fluorescence emission by the chlorophyll of the photosystems makes it possible to carry out nondestructive assays to examine photochemical events during photosynthesis (Almeida and Maestri, 1996; Krause and Somersalo, 1989; Zhang and Schmidt, 2000a). The ratio of variable fluorescence to maximum fluorescence $(\mathrm{Fv} / \mathrm{Fm})$ reflects the photochemical efficiency of PSII or relative photochemical activity (Zhang and Schmidt, 2000a).

Plant growth regulators play an important role in certain turfgrass management systems (Watschke et al., 1992). In recent years, interest in utilizing natural plant growth regulators (NPGR) such as seaweed extract and humic acid in turfgrass management has developed (Coelho et al., 1997; Zhang and
Schmidt, 1999, 2000b). Application of alkaline extracts of the seaweed Ascophyllum nodosum Jol. have been shown to improve turfgrass quality and resistance to environmental stresses such as drought or salinity (Nabati et al., 1994; Zhang and Schmidt, 1999, 2000b). The beneficial effects of seaweed (Ascophyllum nodosum Jol.) extract (SWE) on turfgrass growth have been attributed to the hormones contained in the SWE (Crouch and Van Staden, 1993; Schmidt and Zhang, 1997). Seaweed extracts containing phytohormones influence physiological functions that cannot be substituted by or attributed to application of mineral nutrients (Frankenberger and Arshad, 1995).

Humic acid has long been used in agriculture as a soil supplement and fertilizer (Chen and Aviad, 1990). Several researchers have noted that humic acid improves plant nutrient uptake, increases chlorophyll content, enhances enzyme activity, and promotes stress tolerance (Sladky and Tichy, 1959; Vaughan and McDonald, 1976; Vaughan and Malcolm, 1979; Schmidt and Zhang, 1997, 1998; Zhang and Schmidt, 1999, 2000b). However, the causes of these responses remain unclear. Two hormonal mode of action possibilities for humic acids involve the auxin-like activity reported by O'Donnell (1973) and Nardi et al. (1994) and polyamine content and associated root growth activity reported by Young and Chen (1997).

The role of $\mathrm{Fe}$ in turfgrass management has been studied by Snyder and Schmidt (1973) who noted that Fe fertilization improved the color of cool-season turfgrass grown on non-calcareous soil during cool autumn weather. White and Schmidt (1989) reported that $\mathrm{Fe}$ fertilization improved bermudagrass physiological activity during exposure to chilling temperatures and subsequent recovery. Recent research indicated that extracts of peat and kelp, in combination with $\mathrm{Fe}$, enhanced shoot and root growth of cool-season grasses (Perez-Sanz et al., 1996).

The objectives of this research were to investigate the response of photochemical activity, antioxidant enzyme superoxide dismutase (SOD) activity, root growth, and leaf color to NPGR and Fe in creeping bentgrass grown under two mineral fertilization regimes in the field and low soil moisture under glasshouse conditions.

\section{Materials and Methods}

Field study. This study was conducted at the Virginia Tech Turfgrass Research Center, Blacksburg, Va. from June 1997 through Sept. 1998 on a mature creeping bentgrass (Agrostis palustris Huds., cv. Southshore) area. The soil was a Groseclose silt loam (clayey, Kaolinitic, mesic Typic Hapludult, pH 6.0, O.M. 2.2\%) and the turf was mowed at $0.625 \mathrm{~cm}$ three times weekly. Chipco 26019 FLO (Aventis Environmental Science, Montvale, N.J.) (Iprodione: 3-(3,5-dicholorophenyl)-N-(1-methylethyl)-2,4-dioxo-1imidazolidine carboxamide; a.i. $23.3 \%$ ), a localized penetrant fungicide with relatively 
short efficacy duration, was applied in July and August as a curative control for dollar spot disease caused by Sclerotinia homoeocarpa F.T. Bennett. The turfgrass was irrigated twice a week to supply a total of $5 \mathrm{~cm}$ of water weekly to prevent drought stress.

A split plot design was used with four replications. The main plot consisted of high and low fertilization treatments as follows: 1 ) low fertilization- $\mathrm{N}$ from urea at $2 \mathrm{~g} \cdot \mathrm{m}^{-2} ; \mathrm{P}$ from triple super phosphate $(21 \% \mathrm{P})$ at 0.28 $\mathrm{g} \cdot \mathrm{m}^{-2}$; and $\mathrm{K}$ from potassium chloride $(50 \%$ $\mathrm{K})$ at $1.08 \mathrm{~g} \cdot \mathrm{m}^{-2}$; and 2) high fertilization-N from urea at $5 \mathrm{~g} \cdot \mathrm{m}^{-2}$; $\mathrm{P}$ from triple super phosphate at $0.56 \mathrm{~g} \cdot \mathrm{m}^{-2}$; and $\mathrm{K}$ from potash $2.16 \mathrm{~g} \cdot \mathrm{m}^{-2}$. Urea $(46 \% \mathrm{~N})$ was dissolved in water and the solution was sprayed over the foliage monthly starting on 16 June and ending on 8 Sept. in 1997, and starting on $29 \mathrm{Apr}$. and ending on 10 Sept. in 1998. The total N rates were 8 to $10 \mathrm{~g} \cdot \mathrm{m}^{-2}$ for the low fertilization regime and 20 to $25 \mathrm{~g} \cdot \mathrm{m}^{-2}$ for high fertilization regime. These rates are from local fertilization program recommendations developed by the senior author for the standard maintenance of a bentgrass fairway turf based on years of experimental experience with the soil type, turf species, and area climate. Triple super phosphate (0-46-0) and potassium chloride (0-0-60) were applied to each plot by hand in June and July 1997, and no $\mathrm{P}$ and $\mathrm{K}$ were applied in 1998 . The bentgrass was irrigated immediately after fertilization.

Separate subplots, $1.5 \times 1.8 \mathrm{~m}$, were treated with the two NPGR: SWE at $50 \mathrm{mg} \cdot \mathrm{m}^{-2}$ (estimated as equivalent to an application of kinetin at $25 \mu \mathrm{g} \cdot \mathrm{m}^{-2}$ ) or HA (a.i. 93\% HA) at $150 \mathrm{mg} \cdot \mathrm{m}^{-2}$ alone and in combination with or without $\mathrm{FeSO}_{4}$ at $520 \mathrm{mg} \cdot \mathrm{m}^{-2}$ once a month beginning on 16 June and ending 10 Nov. in 1997, and beginning on 28 Apr. and ending on 10 Sept. in 1998. Solutions of NPGR and Fe were applied evenly over foliage at a rate of $35 \mathrm{~mL} \cdot \mathrm{m}^{-2}$ using a compressed-air sprayer delivering $784 \mathrm{~L} \cdot \mathrm{ha}^{-1}$ at $290 \mathrm{KPa}$. Both SWE and HA were obtained from Plant-Wise Biostimulants (Louisville, Ky.). Iron was obtained from Voluntary Purchasing Groups (Bonham, Texas). The SWE product used is estimated to contain the equivalent of 500 $\mathrm{mg} \cdot \mathrm{L}^{-1}$ of kinetin according to a bioassay using radish (Raphanus sativus L.) cotyledon reported by Acadian Seaplants Limited, Nova Scotia, Canada. The HA used in this study was an extracted source from leonardite; its auxin-like activity has been identified in a bioassay by O'Donnell (1973).

Sample collection for superoxide dismutase (SOD) analysis in Aug. 1997 and 1998 consisted of permitting the grass to grow for one week without mowing and then sampling leaf blade tissue removed by mowing with a 55-cm-wide standard greens-type reel mower set at a $0.625-\mathrm{cm}$ height. Each bulk plot leaf tissue sample was frozen immediately with liquid nitrogen and stored at $20{ }^{\circ} \mathrm{C}$ for SOD activity analysis. The fresh leaf samples $(1000 \mathrm{mg})$ were homogenized in $10 \mathrm{~mL}$ of $0.05 \mathrm{M} \mathrm{Na}_{2} \mathrm{HPO}_{4} / \mathrm{NaH}_{2} \mathrm{PO}_{4}(\mathrm{pH} 7.0)$ buffer. The homogenates were filtered through four layers of cheesecloth and then centrifuged at $4{ }^{\circ} \mathrm{C}$ for $20 \mathrm{~min}$ at $15,000 \times g$. The supernatants were collected and used for SOD assay after an appropriate dilution.

Superoxide dismutase activity was analyzed according to the procedure of Giannopolitis and Ries (1977). One enzyme unit of SOD activity is defined as the amount of enzyme required to cause $50 \%$ inhibition of nitro blue tetrazolium (NBT) reduction measured at $560 \mathrm{~nm}$ on a spectrophotometer.

Function of the photosynthetic system of the turf canopy subjected to darkness for fifteen minutes was probed by measuring chlorophyll fluorescence with a dual wavelength fluorometer(OS-50; Opti-Sciences, Tyngsboro, Mass.) in Aug., Oct., and Dec. 1997 and Mar., May, and Aug. 1998, as described by Zhang and Schmidt (2000a). Photochemical activity (Fv690nm/Fm690nm) was obtained based on chlorophyll fluorescence signals (Zhang and Schmidt, 2000a). An average of three readings from each plot were used for data analysis. Leaf color was evaluated based on a visual scale of 1-9 with 9 indicating darkest green leaf color.

A sod cutter was used to cut a $20 \mathrm{~cm}$ strip from each plot from which plugs $(10 \mathrm{~cm}$ diameter $\times 2 \mathrm{~cm}$ deep) were removed and transplanted into $3-\mathrm{L}$ containers $(15 \mathrm{~cm}$ diameter $\times 17.5 \mathrm{~cm}$ high) on 25 June 1997 and 20 July 1998 . The plugs were grown under a rainout shelter for 4 weeks and irrigated with $0.5 \mathrm{~cm}$ of water by hand twice a week to maintain sufficient soil moisture. Soil was washed from the roots and root weights were determined after being dried at $60^{\circ} \mathrm{C}$ for $24 \mathrm{~h}$.

Glasshouse drought study. Ten-cm-diameter plugs of creeping bentgrass were removed from the treated field plots on 20 July 1997. The soil was trimmed from the plug to $2 \mathrm{~cm}$ and the plugs were transplanted to a clear plastic terrarium that contained $10-\mathrm{cm}-$ deep Groseclose silt loam soil (a clayey, Kaolinitic, mesic Typic Hapludult, pH 6.0, O.M. $2.2 \%$ ) with a soil water potential of -0.5 $\mathrm{MPa}$. The terrariums are designed so as to allow gas exchange, but negligible water loss
(Zhang and Schmidt, 1999). In this manner, the initial soil water potential of $-0.5 \mathrm{MPa}$ was maintained for the duration of the drought trial. Temperatures in the glasshouse-stored terrariums fluctuated between 21 and $26^{\circ} \mathrm{C}$ during the trial with light intensity averaging $\approx 900 \mu \mathrm{mol} \cdot \mathrm{m}^{-2} \cdot \mathrm{s}^{-1}$ at $2 \mathrm{pm}$.

A split-plot arrangement was used with four replications. Each terrarium received a total of six plugs (six NPGR and Fe treatments in one fertilization regime). A total of eight terrariums were used and randomly arranged. The terrariums were opened once a week to check disease and increase gas exchange, and then re-randomized after resealing. Based on a separate experiment, the plastic cover permits air exchange between inside the container and outside while preventing water vapor inside the container from escaping (Zhang and Schmidt, 2000a). Once a week a Thetaprobe soil moisture sensor (ML1; Delta-T Devices, Cambridge, U.K.) was used to check the terrarium soil moisture level which remained constant during the experiment. Six weeks after the plugs were initially placed in the terrariums, chlorophyll fluorescence was measured and leaf samples were collected for the SOD analysis as described previously.

Data from the glasshouse and the field experiments were subjected to analysis of variance (ANOVA). The data from 1997 and 1998 were analyzed separately because the year was not considered as a variable in the experimental design. Each data set from each year was subjected to ANOVA and main effects and the interactions of the two factors (fertilization and NPGR treatment) were evaluated. Since the interactions for each data set were nonsignificant, mean separations for NPGR treatments were ascertained with Duncan's multiple range test based on the averages across two fertilization regimes.

\section{Results and Discussions}

Field study. When measured in Aug. 1997, application of SWE + Fe increased bentgrass

Table 1. Photochemical activity (PA) and superoxide dismutase (SOD) activity measured in Aug. 1997 and 1998 of creeping bentgrass as influenced by natural plant growth regulators (NPGR), NPGR + $\mathrm{Fe}$, and fertilization ${ }^{\mathrm{z}}$.

\begin{tabular}{|c|c|c|c|c|c|}
\hline \multirow[b]{2}{*}{ Treatment } & \multirow{2}{*}{$\begin{array}{l}\text { Amount } \\
\left(\mathrm{mg} \cdot \mathrm{m}^{-2}\right)\end{array}$} & \multicolumn{2}{|c|}{$\mathrm{PA}(\mathrm{Fv} / \mathrm{Fm})$} & \multicolumn{2}{|c|}{ SOD activity $\left(\times 10^{3}\right.$ unit $\left.\cdot \mathrm{g}^{-1} \mathrm{DM}\right)$} \\
\hline & & 1997 & 1998 & 1997 & 1998 \\
\hline HA & 150 & $0.446 b^{y}$ & $0.605 \mathrm{ab}$ & $20.5 \mathrm{a}$ & $18.9 \mathrm{ab}$ \\
\hline SWE & 50 & $0.461 \mathrm{ab}$ & $0.642 \mathrm{a}$ & $11.9 \mathrm{~b}$ & $25.5 \mathrm{a}$ \\
\hline $\mathrm{SWE}+\mathrm{HA}$ & $50+150$ & $0.443 \mathrm{~b}$ & $0.643 \mathrm{a}$ & $19.8 \mathrm{a}$ & $23.5 \mathrm{a}$ \\
\hline $\mathrm{SWE}+\mathrm{Fe}$ & $50+520$ & $0.491 \mathrm{a}$ & $0.626 \mathrm{a}$ & $11.8 \mathrm{~b}$ & $26.3 \mathrm{a}$ \\
\hline $\mathrm{SWE}+\mathrm{HA}+\mathrm{Fe}$ & $50+150+520$ & $0.450 \mathrm{~b}$ & $0.633 \mathrm{a}$ & $17.4 \mathrm{a}$ & $23.7 \mathrm{a}$ \\
\hline Control & 0 & $0.432 \mathrm{~b}$ & $0.561 \mathrm{~b}$ & $9.6 \mathrm{~b}$ & $15.8 \mathrm{~b}$ \\
\hline \multicolumn{6}{|l|}{ Fertilization } \\
\hline $2 \mathrm{~g} \mathrm{~N} \mathrm{~m}^{-2} \cdot \mathrm{mo}^{-1}$ & & $0.447 \mathrm{a}$ & $0.677 \mathrm{a}$ & $12.4 \mathrm{~b}$ & $20.8 \mathrm{~b}$ \\
\hline $5 \mathrm{~g} \mathrm{~N} \mathrm{~m}^{-2} \cdot \mathrm{mo}^{-1}$ & & $0.461 \mathrm{a}$ & $0.559 \mathrm{~b}$ & $18.0 \mathrm{a}$ & $26.6 \mathrm{a}$ \\
\hline \multicolumn{6}{|c|}{ Source of variation: } \\
\hline Fertilization & & NS & $*$ & $*$ & $*$ \\
\hline NPGR and $\mathrm{Fe}(\mathrm{N}$ & $+\mathrm{Fe})$ & $*$ & $*$ & $*$ & $*$ \\
\hline Fertilization $\times \mathrm{N}$ & $-\mathrm{Fe}$ & NS & NS & NS & NS \\
\hline
\end{tabular}

${ }^{2}$ The last application in 1997: NPGRs + Fe: 10 Nov.; N fertilization: 8 Sept. The last application in 1998: NPGR + Fe: 10 Sept.; N fertilization: 10 Sept.

${ }^{y}$ Values followed by the same letter within each column are not significantly different at $P=0.05$.

ss, * Nonsignificant or significant at $P=0.05$. 
phytochemical activity (PA) by $14 \%$ (Table 1). In Aug. 1998, all NPGR and Fe treatments, except for HA-alone, increased PA, ranging from $12 \%$ to $15 \%$. When measured in Oct. 1997, SWE and HA alone or in combination improved PA of creeping bentgrass (Table 2). No difference in PA was obtained in Dec. 1997. In May, 1998, all NPGR and Fe treatments significantly increased PA by $13 \%$ to $46 \%$. The data suggest that NPGR-alone or mixed with Fe may improve PA in the following spring. These results are consistent with Schmidt and Zhang (2001) who reported that SWE+HA increased Kentucky bluegrass PA when subjected to drought.

When measured in Aug. 1997, foliar application of HA, HA + SWE and HA + SWE $+\mathrm{Fe}$ increased SOD activity by $81 \%$ to $114 \%$ (Table 1). In Aug. 1998, all the NPGR and Fe, except for HA-alone, enhanced SOD activity of bentgrass, ranging from $49 \%$ to $67 \%$. These results are supported by those of Zhang and Schmidt (1999) who noted that SWE and HA alone or in combination enhanced activity of various antioxidants including SOD in Kentucky bluegrass.

Creeping bentgrass experiences oxidative stress, especially during the summer, where the photosynthetic apparatus is one of the primary targets of oxidative damage (Smirnoff, 1995). Plant antioxidants, such as SOD, protect the photosynthetic apparatus by scavenging reactive oxygen species (Zhang and Schmidt, 2000a). The results of this study suggest that application of NPGR may protect the photosynthetic apparatus and improve photochemical activity by enhancement of antioxidant SOD activity.

The high fertilization treatment had no main effect on PA in 1997, but caused a PA decrease only in Aug. 1998 (Tables 1,2). The high fertilization treatment increased SOD activity in 1997 and 1998.

All NPGR and Fe treatments increased root mass (17\% to 29\%) in Aug. 1997 and 1998, except HA-alone in 1998 (Table 3). High fertilization did not influence root mass in 1997, but reduced root mass when measured in Aug. 1998. Turner and Hummel (1992), in a review of the turfgrass nutrition literature, cited a number of reports showing that high levels of available nitrogen enhance shoot production, often at the expense of root maintenance and growth. The data obtained in this study suggest that SWE, SWE + HA, $\mathrm{SWE}+\mathrm{Fe}$, and SWE + HA + Fe caused an increase in root dry weight regardless of fertilization (Table 3). Increased shoot and root development has been reported on coolseason grasses after winter or summer applications of products containing humic substances and Fe (Perez-Sanz et al., 1996). Enhancement of root growth by NPGR may be associated with their hormone-like activity and stimulation of endogenous antioxidants (Cacco and Dell'Agnola, 1984; Nardi et al., 1994; O'Donnell, 1973; Sanderson and Jameson, 1986; Young and Chen, 1997; Zhang and Schmidt, 1999).

When evaluated in Oct. 1997, all the NPGR and Fe treatments, except HA-alone, signifi- cantly improved leaf color (Table 4). In subsequent November and December observations, the treatments containing Fe enhanced leaf color. When measured in Jan. 1998, all NPGR and Fe treatments, except for SWEalone, significantly improved creeping bentgrass leaf color. Previous results by Snyder and Schmidt (1973), White and
Schmidt (1989) and Schmidt and Chalmers (1993) also indicated that $\mathrm{Fe}$ or $\mathrm{Fe}+\mathrm{SWE}$ improved leaf color of creeping bentgrass, bermudagrass, and Kentucky bluegrass. Blunden et al. (1997) reported that plants treated with seaweed extract had higher relative chlorophyll contents, indicating leaf color improvement may be closely associated with

Table 2. Photochemical activity (PA) of creeping bentgrass as influenced by natural plant growth regulators (NPGR), NPGR + Fe, and fertilization

\begin{tabular}{|c|c|c|c|c|c|}
\hline \multirow[b]{3}{*}{ NPGR and Fe } & \multirow{3}{*}{$\begin{array}{c}\text { Amount } \\
\left(\mathrm{mg} \cdot \mathrm{m}^{-2}\right)\end{array}$} & \multicolumn{4}{|c|}{ PA (Fv/Fm) } \\
\hline & & \multicolumn{2}{|c|}{1997} & \multicolumn{2}{|c|}{1998} \\
\hline & & Oct. & Dec. & Mar. & May \\
\hline HA & 150 & $0.691 \mathrm{a}^{2}$ & $0.516 \mathrm{a}$ & $0.430 \mathrm{a}$ & $0.370 \mathrm{~b}$ \\
\hline SWE & 50 & $0.703 \mathrm{a}$ & $0.519 \mathrm{a}$ & $0.419 \mathrm{ab}$ & $0.425 \mathrm{a}$ \\
\hline $\mathrm{SWE}+\mathrm{HA}$ & $50+150$ & $0.690 \mathrm{a}$ & $0.490 \mathrm{a}$ & $0.448 \mathrm{a}$ & $0.435 \mathrm{a}$ \\
\hline $\mathrm{SWE}+\mathrm{Fe}$ & $50+520$ & $0.687 \mathrm{ab}$ & $0.495 \mathrm{a}$ & $0.462 \mathrm{a}$ & $0.438 \mathrm{a}$ \\
\hline $\mathrm{SWE}+\mathrm{HA}+\mathrm{Fe}$ & $50+150+520$ & $0.680 a b$ & $0.520 \mathrm{a}$ & $0.416 \mathrm{ab}$ & $0.469 \mathrm{a}$ \\
\hline Control & 0 & $0.667 \mathrm{~b}$ & $0.511 \mathrm{a}$ & $0.389 \mathrm{~b}$ & $0.329 \mathrm{c}$ \\
\hline \multicolumn{6}{|l|}{ Fertilization } \\
\hline $2 \mathrm{~g} \mathrm{~N} \mathrm{~m}^{-2} \cdot \mathrm{mo}^{-1}$ & & $0.665 \mathrm{a}$ & $0.506 \mathrm{a}$ & $0.424 \mathrm{a}$ & $0.417 \mathrm{a}$ \\
\hline $5 \mathrm{~g} \mathrm{~N} \mathrm{~m}^{-2} \cdot \mathrm{mo}^{-1}$ & & $0.669 \mathrm{a}$ & $0.511 \mathrm{a}$ & $0.430 \mathrm{a}$ & $0.405 \mathrm{a}$ \\
\hline \multicolumn{6}{|l|}{ Source of variation: } \\
\hline Fertilization & & NS & NS & NS & NS \\
\hline NPGR and $\mathrm{Fe}(\mathrm{NPGR}+\mathrm{Fe})$ & & * & NS & $*$ & ** \\
\hline Fertilization NPGR + Fe & & NS & NS & NS & NS \\
\hline
\end{tabular}

${ }^{2}$ Values followed by same letter within each column for NPGR + Fe or fertilization are not significantly different at $P=0.05$.

Ns, ,***Nonsignificant or significant at $P=0.05$, or 0.01 , respectively.

Table 3. Root mass of creeping bentgrass as influenced by natural plant growth regulators (NPGR), NPGR + Fe, and fertilization (1997-98)

\begin{tabular}{lccc}
\hline \hline & $\begin{array}{c}\text { Amount } \\
\left(\mathrm{mg} \cdot \mathrm{m}^{-2}\right)\end{array}$ & \multicolumn{2}{c}{ Root dry wt $\left(\mathrm{mg} \cdot \mathrm{cm}^{-3}\right)$} \\
\cline { 2 - 4 } Treatment & 150 & $2.50 \mathrm{a}^{2}$ & Aug. 1998 \\
\hline $\mathrm{HA}$ & 50 & $2.11 \mathrm{~b}$ & $0.68 \mathrm{~b}$ \\
$\mathrm{SWE}$ & $50+150$ & $2.13 \mathrm{~b}$ & $0.75 \mathrm{a}$ \\
$\mathrm{SWE}+\mathrm{HA}$ & $50+520$ & $2.39 \mathrm{a}$ & $0.75 \mathrm{a}$ \\
$\mathrm{SWE}+\mathrm{Fe}$ & $50+150+520$ & $1.85 \mathrm{~b}$ & $0.80 \mathrm{a}$ \\
$\mathrm{SWE}+\mathrm{HA}+\mathrm{Fe}$ & 0 & $0.84 \mathrm{c}$ & $0.64 \mathrm{~b}$ \\
Control & & & \\
Fertilization & & $2.08 \mathrm{a}$ & $0.76 \mathrm{a}$ \\
$2 \mathrm{~g} \mathrm{~N} \mathrm{~m}^{-2} \cdot \mathrm{mo}^{-1}$ & & $2.27 \mathrm{a}$ & $0.68 \mathrm{~b}$ \\
$5 \mathrm{~g} \mathrm{~N} \mathrm{~m}^{-2} \cdot \mathrm{mo}^{-1}$ & & $\mathrm{NS}$ & $*$ \\
Source of variation: & & $* *$ & $*$ \\
Fertilization & & $\mathrm{NS}$ & $\mathrm{NS}$ \\
NPGR and Fe (NPGR + Fe) & &
\end{tabular}

${ }^{2}$ Values followed by same letter within each column for NPGR $+\mathrm{Fe}$ or fertilization are not significantly different at $P=0.05$.

ns, *** Nonsignificant or significant at $P=0.05$, or 0.01 , respectively..

Table 4. Leaf color of creeping bentgrass as influenced by natural plant growth regulators (NPGR), NPGR + Fe, and fertilization.

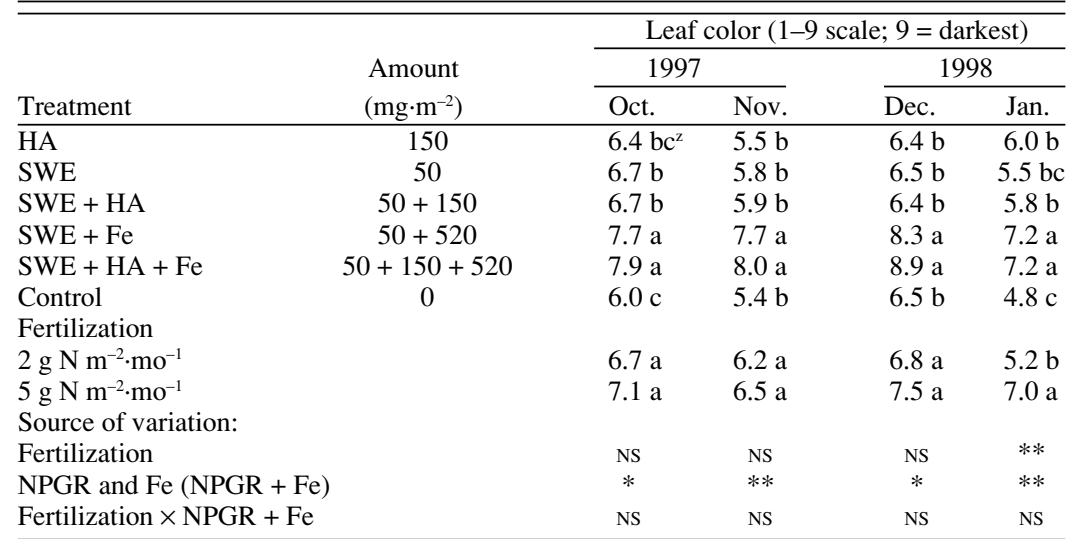

${ }^{2}$ Values followed by same letter within each column for NPGR $+\mathrm{Fe}$ or fertilization are not significantly different at $P=0.05$.

ss, *** Nonsignificant or significant at $P=0.05$, or 0.01 , respectively. 

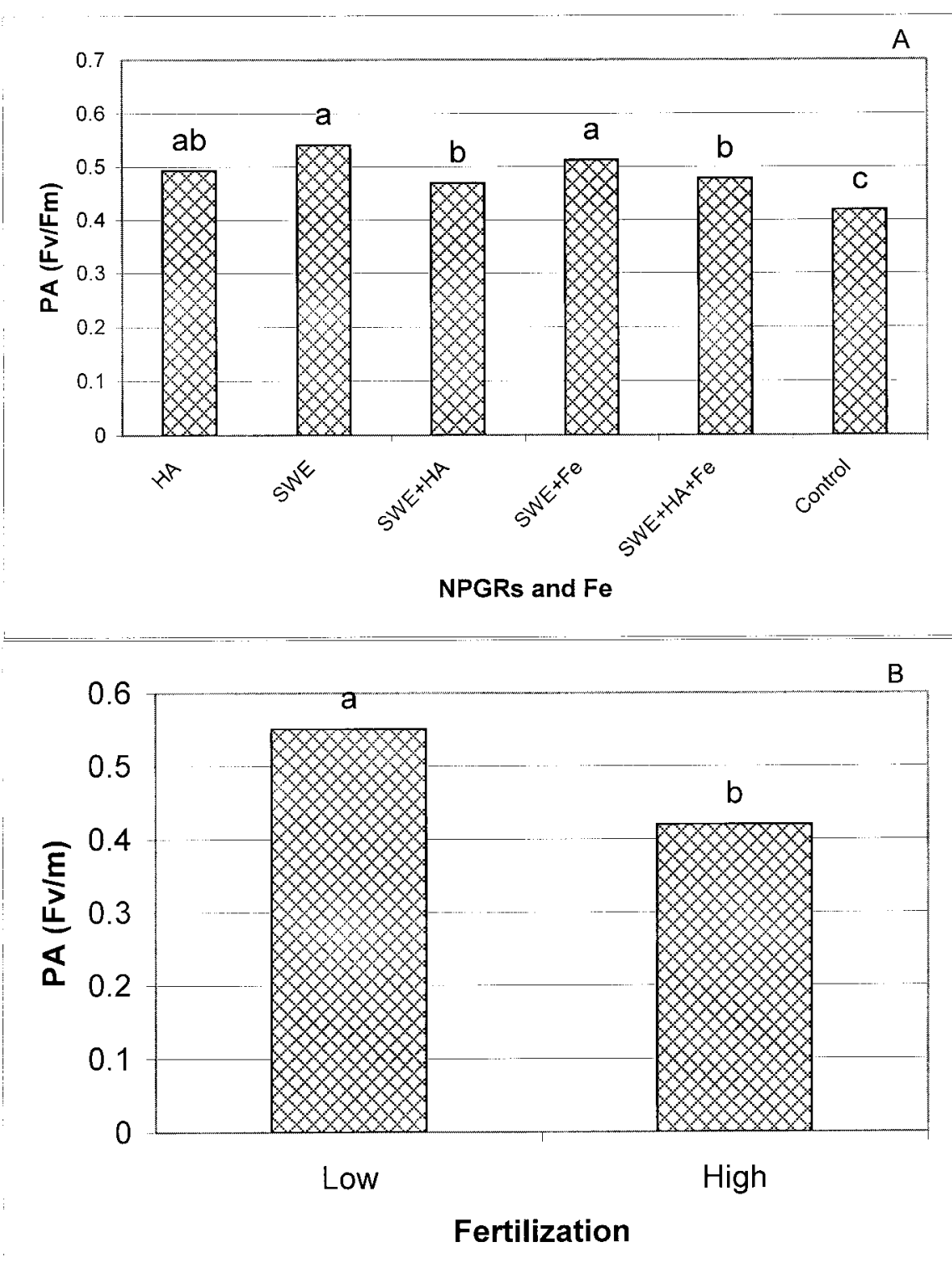

Fig. 1. Photochemical activity (PA; Fv/Fm) (6 Sept.) of creeping bentgrass as influenced by natural plant growth regulators (NPGR) and $\mathrm{Fe}(\mathbf{A})$ and fertilization $(\mathbf{B})$ (plugs of 10 -cm diameter $\times 2$-cm deep were removed from the treated plots in the field on 20 July 1997 and transplanted into terrariums with low soil moisture content $(-0.5 \mathrm{MPa})$ and grown for 6 weeks in a glasshouse; since the fertilization $\times$ NPGR + Fe interaction was nonsignificant at $P=0.05$, the effects NPGR with or without Fe application were the average across two fertilization regimes; $\mathrm{HA}=$ humic acid; $\mathrm{SWE}=$ seaweed extract).

high chlorophyll content in bentgrass treated with NPGR and Fe.

Glasshouse drought study. Under low soil moisture (-0.5 MPa water potential), foliar application of NPGR with or without Fe increased PA by $14 \%$ to $29 \%$ (Fig. 1) and SOD activity by $43 \%$ to $91 \%$ (Fig. 2). High fertilization reduced PA, but had no impact on SOD activity. No fertilization $\times$ NPGR and $\mathrm{Fe}$ interaction was observed for PA or SOD activity in this study. Zhang and Schmidt (2000b) reported that SOD activity was increased when SWE and HA were applied to tall fescue and creeping bentgrass that were subsequently subjected to drought. The results from this study indicate that the NPGR may protect the photosynthetic apparatus of turfgrass subjected to low soil moisture from oxidative damage by enhancement of antioxidant activity.

\section{Conclusions}

The results of these field and greenhouse trials indicate that application of SWE alone or in combination with $\mathrm{HA}$ and Fe significantly increased PA and SOD activity as well as root development especially during the second year of treatment. All NPGR + Fe treatments applied to bentgrass subjected to drought enhanced PA as well as SOD activity regardless of fertilization. These results correspond closely to that of previous studies where it was reported that SWE, HA, or SWE + HA increased Kentucky bluegrass, tall fescue, and creeping bentgrass antioxidant con- tent when subjected to drought in the greenhouse (Zhang and Schmidt, 1999, 2000a). Increased antioxidant content, under artificially-imposed drought or summer field heat stress, has been consistently associated with measurements indicating increased physiological fitness such as greater photochemical activity and root mass maintenance and growth.

Our results indicate that $\mathrm{Fe}$, although having positive late-season leaf greening effects, does not appear to have an additive effect with SWE or HA in terms of increasing bentgrass physiological fitness. Fe-enhanced leaf color did not necessarily correspond to greater PA. Additionally, it was unclear whether higher late-spring through summer monthly $\mathrm{N}$ applications in combination with the NPGR were physiologically beneficial. More detailed research documenting leaf tissue $\mathrm{N}$ levels that are associated with enhanced SOD, PA, and growth levels during abiotic stress remains to be completed.

The results suggest that, in addition to maintaining adequate plant-available nutrients, applications of natural PGRs, such as SWE and HA, prior to and during summer abiotic stresses would be beneficial.

\section{Literature Cited}

Almeida, A.A.F. and M. Maestri. 1996. Characteristics of slow chlorophyll fluorescence emission in four Coffea arabica genotypes submitted to water stress. Photosynthetica 32(2):161-169.

Blunden, G., T. Jenkins, and Y.W. Liu. 1997. Enhanced leaf chlorophyll levels in plants treated with seaweed extract. J. Appl. Physiol. 8(6):535-543.

Cacco, G. and G. Dell'Agnola. 1984. Plant growth regulator activity of soluble humic complex. Can. J. Soil Sci. 64:225-228.

Chen, Y. and T. Aviad. 1990. Effects of humic substances on plant growth. p. 161-186. In: Y. Chen and T. Aviad (eds.). Humic substances in soil and crop sciences. Amer. Soc. Agron. and Soil Sci. Soc. Amer., Madison, Wis.

Coelho, R.W., J.H. Fike, R.E. Schmidt, X. Zhang, V.G. Allen, and J.P. Footenot. 1997. Influence of seaweed extract on growth, chemical composition, and superoxide dismutase activity in tall fescue. Proc. of Amer. Forage Grassl. Council. p. 163-167. Ft. Worth. Tex. 13-16 Apr. 1997.

Crouch, I.J. and Van Staden. 1993. Evidence for the presence of plant growth regulators in commercial seaweed products. Plant Growth Regulat. 13:21-29.

Frankenberger, W.T., Jr., and N. Arshad. 1995. Phytohormones in Soil microbial production and functions. Marcel Dekker, New York.

Giannopolitis, C.N. and S.K. Ries. 1977. Superoxide dismutase. I. Occurrence in higher plants. Plant Physiol. 59:309-14.

Krause, G.H. and S. Somersalo. 1989. Fluorescence as a tool in photosynthesis research. Application in studies of photoinhibition, cold acclimation and freezing stress. Phil. Trans. R. Soc. Land B. 323:281-293.

Nabati, D.A., R.E. Schmidt, and D.J. Parrish. 1994. Alleviation of salinity stress in Kentucky bluegrass by plant growth regulators and iron. Crop Sci. 34:198-202.

Nardi, S., Panuccio, M.R., Abenavoli, M.R., and A. Muscolo. 1994. Auxin-like effect of humic 

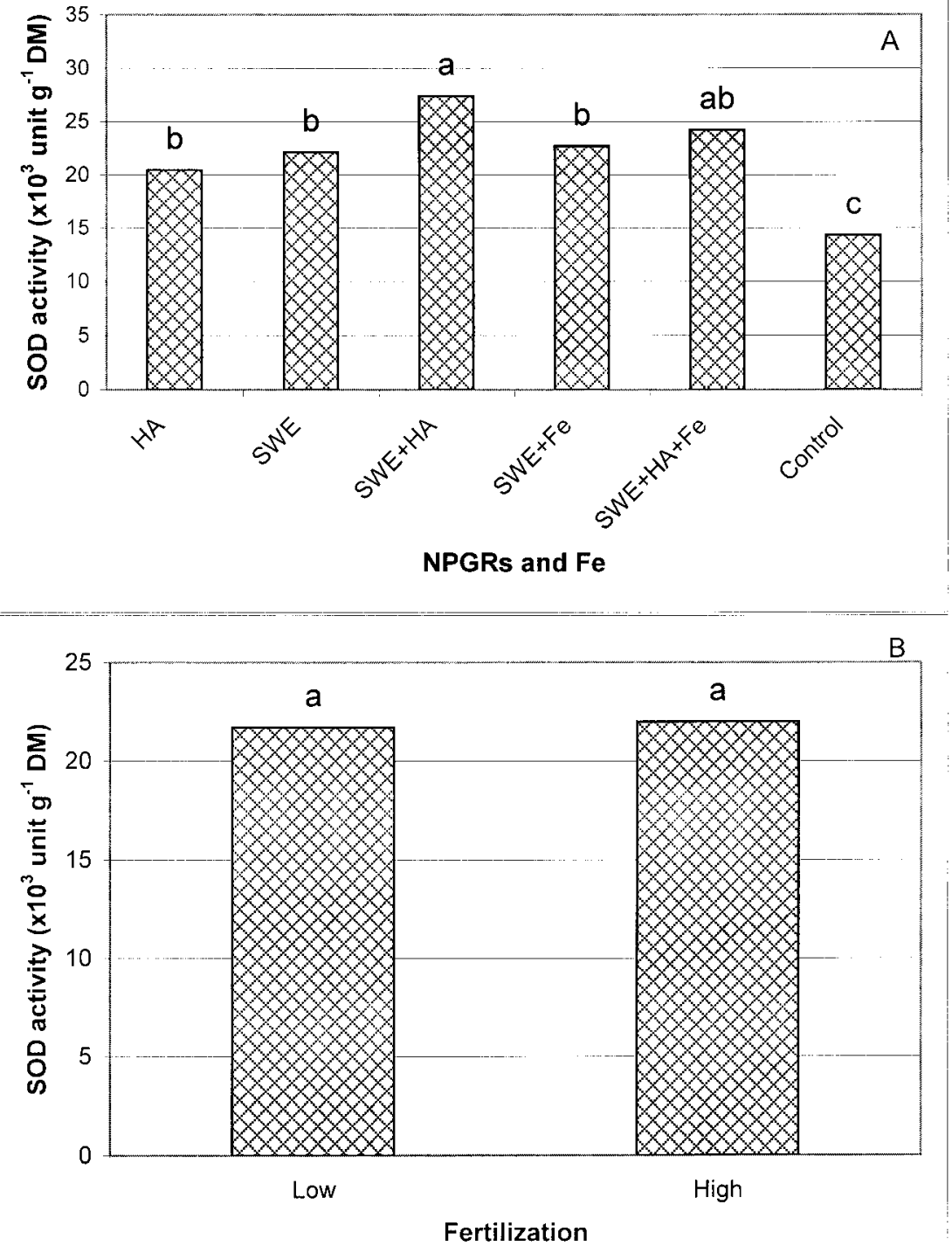

Fig. 2. Superoxide dismutase (SOD) activity (6 Sept.) of creeping bentgrass as influenced by natural plant growth regulators (NPGR) and (A) Fe and (B) fertilization. (Plugs of $10 \mathrm{~cm}$ diameter $\times 2 \mathrm{~cm}$ deep were removed from the treated plots in the field on 20 July 1997 and transplanted into terrariums with low soil moisture content $(-0.5 \mathrm{MPa})$ and grown for 6 weeks in a glasshouse; since the fertilization $\times$ NPGR + Fe interaction was nonsignificant at $P=0.05$, the effects of NPGR with or without Fe application were the average across two fertilization regimes; $\mathrm{HA}=$ humic acid; $\mathrm{SWE}=$ seaweed extract).

substances extracted from faeces of Allolobophora caliginosa and A. rosea. Soil Biol. Biochem. 26:1341-1346.

O'Donnell, R.W. 1973. The auxin-like effects of humic preparations from leonardite. Soil Sci. 116:106-112.

Perez-Sanz, A., E. Eymar, and J.J. Lucena. 1996. Effects of foliar sprays on turfgrasses of extract of peat and kelp amended with iron. J. Plant Nutr. 19:1179-1188.

Sanderson, K.J. and P.E. Jameson. 1986. The cytokin in a liquid seaweed extract: Could they be the active ingredients? Acta Hort. 179:113-116.

Schmidt, R.E. and D.R. Chalmers. 1993. Late summer to early fall application of fertilizer and biostimulants on bermudagrass. Intl.

Schmidt, R.E. and X. Zhang. 1997. Advanced concepts in turfgrass nutrition. Turfgrass Trends 6(2):9-17.

Schmidt, R.E. and X. Zhang. 1998. How humic substances help turfgrass grow. Golf Course Mgmt. 67 (7):65-67.

Schmidt, R.E. and X. Zhang. 2001. Alleviation of Turfgrass Res. J. 7:715-721. photochemical activity decline of turfgrasses exposed to soil moisture stress or UV radiation. Intl. Turfgrass Res. J. 9:340-346.

Sladky, Z. and V. Tichy. 1959. Applications of humus substances to overground organs of plants. Biol. Plant. 1:9-15.

Smirnoff, N. 1995. Antioxidant systems and plant response to the environment, p. 217-244. In: N. Smirnoff (ed.). Environment and plant metabolism: Flexibility and acclimation. BIOS Scientific Publishers. Oxford, U.K.

Snyder, G.H. and R.E. Schmidt. 1973. Some aspects of nitrogen and iron fertilization of bentgrass. p.131-144. In: E.C. Roberts (ed.). Proc. $2^{\text {nd }}$ Intl. Turfgrass Res. Conf., Amer. Soc. Agron., Madison, Wis.

Turner, T.R. and N.W. Hummel, Jr. 1992. Nutritional requirements and fertilization. p. 385440. In: D.V. Waddington, D.V., R.N. Carrow, and R.C. Shearman (ed.). Turfgrass. Amer. Soc. of Agron., Crop Sci. Soc. Amer., and Soil Sci. Soc. Amer. Madison, Wis.

Vaughan, D. and R.E. Malcolm. 1979. Effect of humic acid on invertase synthesis in roots of higher plants. Soil Biol. Biochem. 11:247272.

Vaughhan, D. and I.R. McDonald. 1976. Some effects of humic acid on the cation uptake by parenchyma tissue. Soil Biol. Biochem. 8:415421.

White, R. H. 1996. Physiological basis for selection of bentgrass with superior drought resistance. Turfgrass and Environmental Research Summary. p. 28-29. U.S. Golf. Assn., Far Hills, N.J.

White, R.H. and R.E. Schmidt. 1989. Fall performance and post-dormancy growth of 'Midiron' bermudagrass in response to nitrogen, iron, and benzyladenine. J. Amer. Soc. Hort. Sci. 115(1):57-61.

Watschke, T.L, M.G. Prinster, and J.M. Breuninger. 1992. Plant growth regulators and turfgrass management, p. 558-588. In: D.V. Waddington, R.N. Carrow, and R.C. Shearman (eds.). Turfgrass. Amer. Soc. of Agron., Crop Sci. Soc. Amer., and Soil Sci. Soc. Amer., Madison, Wis.

Young, C.C. and L.F. Chen. 1997. Polyamines in humic acid and their effect on radical growth of lettuce seedlings. Plant and Soil. 195:143-149.

Zhang, J. and M.B. Kirkman. 1994. Drought-stress induced changes in activities of superoxide dismutase, catalase, and peroxidase in wheat species. Plant Cell Physiol. 35:785-791.

Zhang, X. and R.E. Schmidt. 1999. Antioxidant response to hormone-containing product in Kentucky bluegrass subjected to drought. Crop Sci. 39:545-551.

Zhang, X. and R. E. Schmidt. 2000a. Application of trinexapac-ethyl and propiconazole enhances superoxide dismutase and photochemical activity in creeping bentgrass (Agrostis stoloniferous var. palustris). J. Amer. Hort. Sci. 125:47-51.

Zhang, X. and R.E. Schmidt. 2000b. Hormonecontaining products' impact on antioxidant status of tall fescue and creeping bentgrass subjected to drought. Crop Sci. 40:1344-1349. 